\section{Crowded universities cramp more than just students' style}

Sir-Many of the comments made by David Swinbanks (Nature 403, 7; 2000) about the serious problems in Japanese universities are valid. Laboratory space in most universities is severely limited; overcrowded laboratories can be seen everywhere. Visitors from abroad are often appalled by these poor conditions and wonder why nothing is being done about them.

The main reason for the deterioration of facilities has been a lack of investment by the government in higher education and in university research over many years, even when Japan was in a period of economic growth. The recent government policy of increasing the number of graduate students without proper investment in university buildings (see figure) has aggravated the problem. University authorities who accepted more graduate students without requesting the proper investment share the responsibility for this situation.

The figure shows how the number of graduate students in Japanese national universities has increased without a concurrent increase in space. The Ministry of Education, Science, Culture and Sports (Monbusho), which is mainly responsible for these matters, expects a further increase from the current 180,000 to 250,000 in 2010 . That would make the situation even worse.

Swinbanks suggests that Japanese scientists must learn to take action. But they have made efforts previously to do something about poor conditions. A survey by the Chemical Society of Japan (Nature 339, 575; 1989), backed by media reports and by a strong appeal from the then president of Tokyo University, Akito Arima, forced a recognition of the miserable university research conditions in the late 1980s and early 1990s. This led to legislation in support of science and technology and to a boost in funding. However, the biggest and the most fundamental problem, that of upgrading university facilities, still remains.

At present, the Japanese government does not make public its spending priorities. It would seem sensible to provide enough research space first, and then, when the infrastructure is in place, pump in more money for the actual research. But things do not proceed that way in Japan. Arima used to be a strong advocate for the improvement of research conditions, and later became the head of both Monbusho and the Science and Technology Agency. But he was not very
Increase in number of graduate students at national universities vs the floor area of national institutes

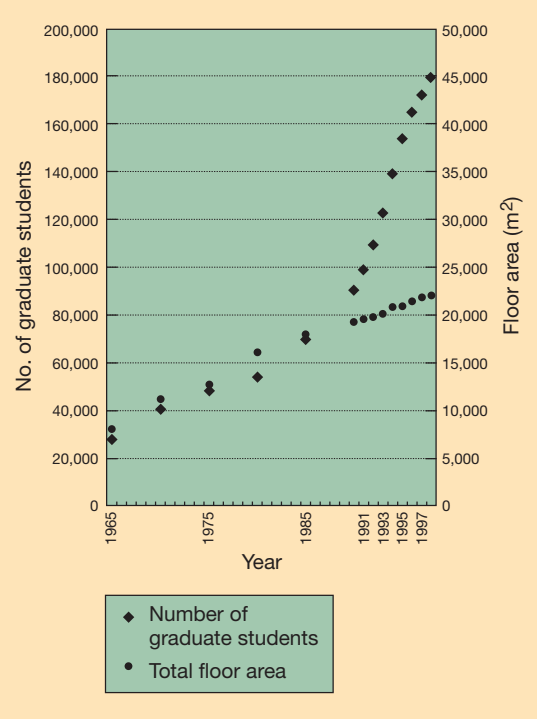

Going through the roof: student numbers are rising faster than the space available for them.

successful, during his short term, in improving matters in Japan's political and bureaucratic framework. Other ministries seem to regard the problems of university facilities as matters for Monbusho alone, and they resist attempts to change the way in which public money is shared out among ministries.

The Science Council of Japan, an advisory organization for government comprising 210 members elected from various scholarly societies, made a survey of space problems and unanimously recommended that the government take urgent measures to improve the situation. But the reaction of Japan's general media has been far from enthusiastic. Most politicians are either unaware of the problem or are uninterested in it.

I hope the government will place the highest priority on construction of university buildings in its next five-year plan for Science and Technology.

Akio Yamamoto

Department of Applied Chemistry, Waseda

University, 3-4-1 Ohkubo, Sinjuku-ku, Tokyo 169-8555, Japan

\section{Patent confusion in law on new plant varieties}

Sir-The news (Nature 403, 3; 2000) that the European Patent Office (EPO) has reversed its decision in the Plant Genetic Systems case gives cause for concern. How and why has the Enlarged Technical Board of Appeal — which made the original decision - changed its mind?
Originally, the application for a patent on Plant Genetic Systems plants was refused because the EPO decided that the material described as 'plant cells and their resulting plants' was de facto a plant variety and was therefore unpatentable. The EPO said that the stable incorporation of foreign DNA into the genome of an existing variety merely made another variety — and thus the reconstituted plants were covered by the regulations of the International Union for the Protection of New Varieties of Plants.

The original Enlarged Board of Appeal took the most narrow definition possible of a plant variety - that is, that the incorporation of a single gene is enough to differentiate one variety from another.

Yet the EPO has now reversed its decision, based on the alleged need for an even narrower definition. This means the EPO has now defined a plant variety as being less than a single gene's separation between two plant lines.

European patent law concerning genetically modified organisms is in a mess, and needs to be completely rethought to balance the commercial, ethical and scientific aspects of this difficult question. The European Directive on Patenting Biotechnological Inventions is full of ambiguity and contradictions so much so that two European Union states have already referred it to the European Court.

The EPO's latest decision has made it harder for biotech companies to argue their case from an environmental perspective. How will they be able to say that their products are no more risky than conventionally bred crops, while at the same time arguing that their plant and animal creations are patentable inventions and thus, by definition, new? It will not take long for organizations such as Greenpeace to start using this as an argument against genetically modified organisms.

On the same page as the news item about the EPO decision was a report that the US Patent Office has tightened up by disallowing 'speculative claims'. Even more interestingly, these new guidelines are to remain open for public comment on a website until $22 \mathrm{March}$. This should be a new model of operation for the EPO, whose decisions seem arbitrary and out of touch with the increasing public concern on the patenting issue.

How about an open consensus conference on patenting living things, organized by the EPO, as the basis for an equitable European way out of the quagmire of patents for genetically modified organisms?

John R. Porter

Royal Veterinary and Agricultural University, Agrovej 10, 2630 Taastrup, Denmark 